\title{
THE REVIEW OF SOCIAL THEOLOGY AND SCIENCE ON THE BENEFITS OF VACCINE IN THE COVID-19 PREVENTIVE MEASURES
}

\author{
Abd Hannan \\ Institut Agama Islam Negeri Madura \\ Ceguk, Pamekasan, East Java, Indonesia \\ E-mail:hannan.taufiqi@gmail.com \\ Zainuddin Syarif \\ Institut Agama Islam Negeri Madura \\ Ceguk, Pamekasan, East Java, Indonesia \\ E-mail: doktorzainuddinsyarif@gmail.com
}

Ku Abdul Muhaimin Yusof

Princess of Naradhiwas University

Khok Khian, Mueng Narathiwat District, Thailand

E-mail: muhaimin.y@pnu.ac.th

\begin{tabular}{c|c|c}
\hline Received: & Revised: & Approved: \\
23/08/2021 & $22 / 10 / 2021$ & $13 / 12 / 2021$ \\
\hline
\end{tabular}

DOI : 10.32332/akademika.v26i2.3605

\begin{abstract}
The negative public perception of the vaccination is one of the most important concerns that occur while dealing with Covid-19. This viewpoint is based on the belief that vaccinations include ingredients that are prohibited by religion making their usage not halal. This study investigates the benefits of vaccinations in the Covid-19 preventive measures from a theological and scientific standpoint. This study employs qualitative research methods. Primary and secondary data were gathered from a variety of sources, including literature, information media, and statistics data. This study discovered several findings applying the maqashid al-syari'ah theory as an analytical tool: First, vaccines are medical instruments that aim to strengthen the immune system so that it can increase immunity and reduce the risk of Covid-19 transmission; Second, from the stand point of social theology, the role of vaccines in protecting and preventing the body from transmitting Covid-19 is relevant to the dimensions of benefit found in maqashid al-syari'ah, one of which is the protection of the soul or self (hifzu al-Nafs); Third, the religious perspective plays a role in elucidating the reasons for the halal status of the Covid-19 vaccine from the standpoint of its value in social theology. In terms of science's viewpoint, it serves as a tool in articulating how the notion of self-preservation (hifzu al-Nafs) should be implemented through medical goods such as a vaccine.
\end{abstract}

Keywords: Social theology, science, benefits of vaccines, and Covid-19 


\section{A. Introduction}

The Covid-19 pandemic virus (Corona Virus Disease) has been wreaking havoc on the planet for over two years. There has been no evidence that the virus's transmission can be totally stopped since it was first found in Wuhan, China, in December 2019. ${ }^{1}$ In recent months, however, many nations have reported finding new varieties of the virus as a result of mutations of previous viruses. After the Delta variant, which affected numerous Asian nations like India, Malaysia, and Indonesia, a new variety known as the Lambda variant has appeared, which is anticipated to be more dangerous. ${ }^{2}$ While the Delta variant is recognized for having a faster transmission rate and a higher risk of mortality, the Lambda variation is not only faster and more lethal but is also more resistant to medical treatment. ${ }^{3}$ The propagation of the Lambda variant virus, according to epidemiologists, might represent a more serious threat. ${ }^{4}$ To foresee and avoid it, stakeholders must work together to speed and intensify mitigation activities, including cultural mitigation such as keeping a safe distance and reducing crowds, as well as medical structural mitigation, particularly vaccination. ${ }^{5}$

However, given the current status quo, efforts to increase mitigation in the context of dealing with Covid-19 would be extremely difficult. ${ }^{6}$ This anxiety is wellfounded, given that the execution of the Covid-19 response program has been fraught with difficulties and roadblocks. ${ }^{7}$ In addition to structural issues that are related to the policies at the bureaucratic level, cultural issues in the form of the low collectivity of society that is still trapped in anachronistic attitudes and behavior, namely thought patterns or attitudes that promote the traditional way of viewing and fixing current issues, are also a serious problem. ${ }^{8}$ According to Masdar Hilmy (2020), the

${ }^{1}$ Qun Li et al., "Early Transmission Dynamics in Wuhan, China, of Novel CoronavirusInfected Pneumonia," New England Journal of Medicine 382, no. 13 (March 26, 2020): 1199-1207.

2 Ashley Hagen, "How Dangerous Is the Delta Variant (b.1.617.2)?," ASM.Org, last modified July 30, 2021, accessed August 15, 2021, https://asm.org/Articles/2021/July/HowDangerous-is-the-Delta-Variant-B-1-617-2; Vikas Pandey, "Delta Plus Variant: Can India Prevent Third Covid Wave?," BBC News, June 24, 2021, sec. India, accessed August 15, 2021, https://www.bbc.com/news/world-asia-india-57577138.

3 Amy Barret, "Lambda Covid Variant: All You Need to Know About The New UK Coronavirus Strain," BBC Science Focus Magazine, last modified August 9, 2021, accessed August 15, 2021, https://www.sciencefocus.com/news/lambda-variant/; Amy Barret, "Lambda Covid Variant: All You Need to Know About The New UK Coronavirus Strain," BBC Science Focus Magazine, accessed August 15, 2021, https://www.sciencefocus.com/news/lambda-variant/.

${ }^{4}$ Lihat Erni Munastiwi and Siti Marfuah, "The Influence of Assignment Methods on the Development Aspects of Religious and Moral Values of Early Childhood During the Covid-19 Pandemic," Akademika: Jurnal Pemikiran Islam (online); Vol 26 No 1 (2021) (May 24, 2021), https://e-journal.metrouniv.ac.id/index.php/akademika/article/view/3143.

5 Tara Hurst, "Covid: Lambda Variant Is Now In 29 Countries, But What Evidence Do We Have That It's More Dangerous?," The Conversation, last modified July 12, 2021, accessed August 15, 2021, http://theconversation.com/covid-lambda-variant-is-now-in-29-countriesbut-what-evidence-do-we-have-that-its-more-dangerous-163936.

6 Aleena Banerji et al., "COVID-19 Vaccination in Patients with Reported Allergic Reactions: Updated Evidence and Suggested Approach," The Journal of Allergy and Clinical Immunology: In Practice 9, no. 6 (June 1, 2021): 2135-2138.

7 Yi-Chi Wu, Ching-Sung Chen, and Yu-Jiun Chan, "The Outbreak of COVID-19: An Overview," Journal of the Chinese Medical Association 83, no. 3 (March 2020): 34.

8 Zainuddin Syarif and Abd Hannan, "Fundamentalism and the Challenges of Religious Moderation in the New Normal Era," Madania: Jurnal Kajian Keislaman 25, no. 1 (July 1, 2021), 
anachronism motif, in this case, is caused by two elements: cultural factors in the form of a lack of public knowledge to implement and apply health protocols, and cultural factors in the form of a lack of public awareness to implement health protocols. ${ }^{9}$ Anachronisms, in terms of religious factors, can be in the form of endeavors to reject and defy the Covid-19 preventive measures under the pretext of religious literature, both in regulatory countermeasures, such as social distance and prohibitions on assemblies in public places of worship, and in medical ones, such as the distribution of vaccinations to the wider public. ${ }^{10}$

Several studies have been undertaken on the role of religion in the dynamics of dealing with Covid-19, one of which is Masdar Hilmy's research, Winning the Battle of Authorities: Muslim Disputes Over the Covid-19 Pandemic Plague in Contemporary Indonesia (2020). Masdar Hilmy examines the occurrence of two opposing logic poles battling it out in response to the Covid-19 outbreak, between inductive logic represented by scientists on one hand and deductive logic represented by conservative religious groups on the other. ${ }^{11}$ The fight for these two logics spans a wide range of battlegrounds, including social media, information channels, and public spaces. ${ }^{12}$ According to the scientific logic group, Covid-19 is an infectious disease that may spread from one spot to another. Only by implementing mitigation, both in the form of policies and medical interventions, would it be feasible to resist it. One of the medical endeavors is to establish a vaccination program, to reach hard immunity afterward. In contrast to the scientific group's viewpoint, 13 the conservative religious group believes that the management of Covid-19 should not only view to a strictly scientific approach, but it should also include religious considerations. ${ }^{14}$ In many cases, religious organizations sometimes have doubts regarding attempts to fight Covid-19 and have accused the epidemic of being part of a global conspiracy to undermine religion's existence. ${ }^{15}$

https:// ejournal.iainbengkulu.ac.id/index.php/madania/article/view/4260; Abd Hannan, Siti Azizah, and Husna Atiya, "Dinamika Pesantren Dalam Merespons Pandemi Covid-19 Di Madura," DINIKA : Academic Journal of Islamic Studies 5, no. 2 (December 30, 2020), http:// ejournal.iainsurakarta.ac.id/index.php/dinika/article/view/2923.

9 Masdar Hilmy, "Sikap Ilmiah Menghadapi Pandemi Covid-19," Kolom UINSA, April 4, 2020, accessed July 4, 2020, https://w3.uinsby.ac.id/sikap-ilmiah-menghadapi-pandemi-covid$19 /$.

${ }^{10}$ Abd Hannan, Fithriyah Rahmawati, and Ahmad Imam Khairi, "The Moderatism and Religious Conservatism Problems in the Middle of Covid-19 Pandemic Era" 13 (n.d.): 31; Zainuddin Syarif and Abd Hannan, "Fundamentalism and the Challenges of Religious Moderation in the New Normal Era," Madania: Jurnal Kajian Keislaman 25, no. 1 (July 1, 2021), https:// ejournal.iainbengkulu.ac.id/index.php/madania/article/view/4260.

${ }^{11}$ Lihat Suyadi, Zalik Nuryana, and Niki Alma Febriana Fauzi, "The Fiqh Of Disaster: The Mitigation of Covid-19 in the Perspective of Islamic Education-Neuroscience," International Journal of Disaster Risk Reduction 51 (December 1, 2020): 101848.

12 Masdar Hilmy and Khoirun Niam, "Winning the Battle of Authorities: The Muslim Disputes Over the Covid-19 Pandemic Plague in Contemporary Indonesia," QIJIS (Qudus International Journal of Islamic Studies) 8, no. 2 (December 31, 2020): 293.

13 See Joseph Renus F Galang, "Science and Religion for Covid-19 Vaccine Promotion," Journal of public health (Oxford, England) 43, no. 3 (September 22, 2021): e513-e514.

${ }^{14}$ See Heidi A. Campbell and Zachary Sheldon, "Religious Responses to Social Distancing Revealed through Memes during the COVID-19 Pandemic," Religions 12, no. 9 (2021).

${ }^{15}$ See juga Will Jennings et al., "Lack of Trust, Conspiracy Beliefs, and Social Media Use Predict COVID-19 Vaccine Hesitancy," Vaccines 9, no. 6 (2021); Mohamed Boudjelal et al., 
In addition to Masdar Hilmy's publications, Wafi Muhaimin's research entitled the Theological Benefit of Social-Physical Distancing in Covid-19 Management (2020) investigates the role of religion in the dynamics of dealing with Covid-19. Wafi Mahaimin said that, although efforts to overcome Covid-19 through medical techniques have gained a theological foundation, many individuals still reject the Covid-19 mitigation program for religious foundation, including the rejection of regulation, policy, and medical mitigation, such as vaccination. ${ }^{16}$ Concerning this research findings, according to a survey conducted by the Ministry of Religion's Research and Development Center in December 2020, out of a total of 2,610 respondents from 34 provinces in Indonesia, 57.66 percent declined to get vaccinated due to religious reasons. Their reasons are varied, including skepticism about the vaccine's halal status and concerns about the vaccine's harmful side effects, which might do greater harm to the body's health. ${ }^{17}$

Based on the framework outlined above, the purpose of this study is to perform a focused investigation on the religious and scientific advantages of vaccination in the fight against Covid-19. This research is significant because it focuses on performing a study to find answers to questions about the societal advantages of vaccination, which has sparked debate and long-running disputes among religious scholars and scientists. Furthermore, in order to provide in-depth and critical analysis results, this study is based on two perspectives at the same time: theological and scientific perspectives. At the same time, this takes on its own uniqueness and novelty, which has never been conducted or exposed in previous socio-religious studies. The phrase "religious viewpoint" is used in this research to refer to the meaning of Islamic theology and all of its elements, both historical and textual.

This study argues that the use of vaccination as a medical approach to dealing with and regulating Covid-19 has a truth value, both scientifically and spiritually. A vaccination, based on a scientific standpoint, is a medical science product that is created through a process of research, testing, and experiment carried out by professionals. The Covid-19 vaccine, like other vaccinations, has the primary goal of protecting the body and building self-defense so that it can be protected from the Covid-19 virus. Besides, based on a religious (Islamic) perspective, vaccinations find a place for truth in religious teachings for Muslims to take care of themselves (hifdzu annas). One of the five fundamental principles of sharia in Islam is to preserve and care for one's own health. Self-preservation entails safeguarding against everything hazardous or life-threatening. This study employs qualitative research methods. Primary and secondary data were gathered from a variety of sources, including literature, information media, and statistics data.

\section{B. Covid-19 in the Perspective of Religion and Science}

Coronavirus Disease 2019, also known as Covid-19, is one of the contemporary

"Covid-19 Vaccines: Global Challenges and Prospects Forum Recommendations," International Journal of Infectious Diseases 105 (April 1, 2021): 448-451.

16 Abd Hannan and Wafi Muhaimin, 'Teologi Kemaslahatan Social-Phsycal Distancing dalam Penanggulangan Covid-19', Kuriositas; Media Komunikasi Sosial dan Keagamaan 13, no. 1 (June 2020): 78-102; Lihat juga Abd Hannan and Heny Triyaningsih, 'Mitigasi Covid-19 melalui Kearifan Lokal Pesantren di Madura' 6 (2020): 30.

17 Balitbangdiklat Kemenag, "Respon Dan Kesiapan Umat Beragama Atas Rencana Vaksinasi Covid-19," Balitbangdiklat.Kemenag.Go.Id, last modified January 13, 2021, accessed August 15, 2021, https://balitbangdiklat.kemenag.go.id/berita/respon-dan-kesiapan-umatberagama-atas-rencana-vaksinasi-covid-19. 
malignant viruses that can cause acute respiratory illnesses, according to scientists. As a result, the transmission not only poses a health risk but also poses a risk of death. 18 This disease was initially designated as Novel Coronavirus Disease (2019-nCoV) when it was identified in Wuhan City, Hubei Province, China, in December 2019. However, the World Health Organization (WHO) renamed it to Coronavirus Disease (Covid-19) in February 2020.19 This name is derived from the virus's attack on the respiratory organs, which results in an aberrant breathing system that can lead to death. Although the exact source of the virus is still unknown, the first patient case (zero patient) has always been linked to a fish market in Wuhan, China. Therefore, the notion that this virus arose as a result of a laboratory leak at the Wuhan Institute of Virology in China has gained traction. ${ }^{20}$

Covid-19, like other viruses, may spread from one object to another. This virus can be spread in a variety of ways. It can be transmitted through direct contacts, such as touching and physical contact, as well as indirect contact, such as holding an inanimate object that has been exposed to the virus earlier. ${ }^{21}$ Covid-19 becomes more stable in items like this, especially when exposed to plastic and stainless steel. ${ }^{22}$ Coughing fluids may persist on inanimate items such as doorknobs, tables, and chairs, according to studies conducted at several research institutions. ${ }^{23}$ Covid-19 can last up to 4 hours on copper-based things and up to 24 hours on cardboard-based objects. ${ }^{24}$ Therefore, using personal protective equipment like masks and hand sanitizers can help minimize virus transmission via droplets. ${ }^{25}$ Meanwhile, social mitigation efforts against the existence of Covid-19 can be carried out through basic protection, such as diligently washing hands with soap, maintaining social distance in the form of social and physical distancing, and avoiding social activities that can invite crowds, including crowds of religious worship rituals. ${ }^{26}$

What about religious views? Concerning this issue, Islam, as a religion with

18 Cucunawangsih Cucunawangsih et al., "Post-Vaccination Cases of COVID-19 among Healthcare Workers at Siloam Teaching Hospital, Indonesia," International Journal of Infectious Diseases 107 (June 1, 2021): 268-270.

$19 \mathrm{Wu}$, Chen, and Chan, "The Outbreak of COVID-19," 34.

20 Aiping Wu et al., "Genome Composition and Divergence of the Novel Coronavirus (2019-NCoV) Originating in China," Cell Host \& Microbe 27, no. 3 (March 2020): 325-328.

21 Boudjelal et al., "Covid-19 Vaccines: Global Challenges and Prospects Forum Recommendations."

${ }^{22}$ Mike Lonergan and James D. Chalmers, "Estimates of the Ongoing Need for Social Distancing and Control Measures Post-'Lockdown' from Trajectories Of Covid-19 Cases and Mortality," European Respiratory Journal 31, no. 2 (June 1, 2020): 2001483.

${ }^{23}$ AlAnoud TofailAhmed Raja, Aws Alshamsan, and Ahmed Al-jedai, "Current Covid-19 Vaccine Candidates: Implications in the Saudi Population," Saudi Pharmaceutical Journal 28, no. 12 (December 1, 2020): 1743-1748; Michela Antonelli et al., "Risk Factors And Disease Profile Ff Post-Vaccination Sars-Cov-2 Infection in UK Users of the Covid Symptom Study App: A Prospective, Community-Based, Nested, Case-Control Study," The Lancet Infectious Diseases, accessed October 21, 2021, https:/ / doi.org/10.1016/S1473-3099(21)00460-6.

24 Jie Cui, Fang Li, and Zheng-Li Shi, "Origin and Evolution of Pathogenic Coronaviruses," Nature Reviews Microbiology 17, no. 3 (March 2019): 181-192.

25 Martin C.S. Wong et al., "Acceptance of the Covid-19 Vaccine Based on the Health Belief Model: A Population-Based Survey in Hong Kong," Vaccine 39, no. 7 (February 12, 2021): 1148-1156.

26 Arifur Rahman and Atanu Sarkar, "Risk Factors for Fatal Middle East Respiratory Syndrome Coronavirus Infections in Saudi Arabia: Analysis of the WHO Line List, 2013-2018," American Journal of Public Health 109, no. 9 (July 18, 2019): 1288-1293. 
teachings and principles, has its own viewpoint. In general, Islam categorizes disease into three categories: disease as a life's problem, disease based on previous conduct, and disease that causes death. ${ }^{27}$ The first two classes of disease are classified as sorts of diseases for which treatment is still possible. The last kind of disease, namely, a disease that results in death, is the only one that cannot be healed, either by current medical technology or spiritual healing techniques. A disease in the form of germs or bacteria, which can spread and be transmitted from one person to another and from one location to another, is one type of disease among all of the following sorts. This sort of infectious sickness is commonly referred to as Tha' $u n$ and Waba' in Islam. ${ }^{28}$

Tha'un is a contagious and extensively disseminated disease in Islam. ${ }^{29}$ This disease has the potential to spread through the air, pollute, and ultimately infect people. This disease is considered aggressive, and everyone who acquires it faces the possibility of death. Many historical and literary interpretations exist for the Islamic explanation of Tha'un. Ibn Hajar al-Asqalani outlines two outbreaks in Islamic history in his books. First, it occurred during the time of the Prophet Muhammad. The invasion of the Kaaba in Mecca by Abraha was thwarted because the leader of Habasyah and his warriors were infected by smallpox. Second, Tha'un occurred under the reign of Umar ibn Khattab. The contagious illness of Tha'un ravages the Arabian peninsula during his dominion. Baghdad, Algeria, and Iraq were among the most hit. Up to 25 thousand individuals died as a result of the Tha' $u$ n disease during this period. ${ }^{30}$ In the subsequent time, the Thau' $n$ resurfaced in the 14 th century and was termed the "Black Death" at the time. Two-thirds of the inhabitants of the European continent and its environs died as a result of the plague that struck between 1346 and 1353 . The victims could reach 70 thousand people in a single day. ${ }^{31}$

In his work Badzlu al Maun Fi Fadhli al Thaun (1372-1449), al-Hafiz Ibn Hajar alAsqalani noted that the name Tha'un in Islam has the same meaning as the pandemic that exists today. ${ }^{32}$ Both Tha'un and the plague are contagious illnesses that have spread over the world. Both have the ability to infect anybody and any group. It has no preference for gender, ethnicity, nation, or religion. Now, the question is "what is the difference between Tha'un and Waba' in Islam? Still, according to Hajar alAsqalani, distinguishing between the two is complex because they are both potentially contagious in the form of bacteria. In a nutshell, $W a b a^{\prime}$ refers to the disease itself. Every Tha'un is $W a b a^{\prime}$, but not vice versa. Waba' is a disease that is both

27 Basem Attum et al., "Cultural Competence in the Care of Muslim Patients and Their Families," in StatPearls (Treasure Island (FL): StatPearls Publishing, 2020), accessed July 15, 2020, http:/ / www.ncbi.nlm.nih.gov/books/NBK499933/.

28 Teuku Kemal Fasya, "Covid-19 dan Dekonstruksi Teologis," Media Indonesia, last modified April 3, 2020, accessed July 2020, https://mediaindonesia.com/read/detail/300915-covid-19-dan-dekonstruksi-teologis.

29 Mukharom Mukharom and Havis Aravik, "Kebijakan Nabi Muhammad Saw Menangani Wabah Penyakit Menular Dan Implementasinya Dalam Konteks Penanggulangan Coronavirus Covid-19," SALAM: Jurnal Sosial dan Budaya Syar-i 7, no. 2 (March 24, 2020).

30 A.Syalaby Ichsan, 'Tiga Hadis tentang Thaun yang Mesti Anda Ketahui', Republika Online, 11 April 2020, https:/ / republika.co.id/share/q8mbkw483.

31 republika.id, "Thaun Dan Waba Dalam Turos Ulama," Republika.Id, last modified July 14, 2020, accessed July 15, 2020, https://republika.id/posts/5760/thaun-dan-waba-dalamturos-ulama.

32 LIhat Ibn Hajar Al-Asqalany, , Bażl Al-Mā'ūn Fi Fạ̣ Li al-T à̃ūn ((Riyadh: Dār alAshimah, 1991). 
endemic and pandemic, whereas Tha' $u n$ is a contagious and fatal illness. ${ }^{33}$

As a result of the above explanations, it appears that there is a common thread that the discussion of infectious diseases (viruses, epidemics) in religion is not a new phenomenon. When contextualized with current issues and realities, the disease of Tha'un and Waba' in Islam has the same context and significance as the disease outbreak that has ravaged the world in recent decades. The Covid-19 epidemic, for example, is presently infecting millions of individuals all over the world.

\section{The Covid-19 Countermeasures: a Religious and Scientific Approach}

As previously stated, infectious illnesses are acknowledged by both religion and science. As secular Islamic organizations have demonstrated, there is no contradiction between them. Even in terms of handling the disease, both agree that Covid-19 is a serious disease that should be avoided at all costs. Even if religion and science have distinct ways of looking at things in particular situations, they are complementary and mutually reinforcing. The interaction with this pattern, according to John F. Haught, is a representation of the integration of religion and science, where religion and science may build a pattern of constructive discourse, rather than the destructive dialogue espoused by secularism and religious conservatism. ${ }^{34}$

Religion categorizes Infectious illnesses as hazardous diseases that can endanger persons, their family members, and the society at large. As a result, Islam encourages its followers to take care of themselves. ${ }^{35}$ The term "self-preservation" has a broad definition. This is due to the fact that Islam is a religion founded on the spirit of rahmatanlil'alamin. What's within has a lot of relevancies with the changes of the times, as well as social issues like the current worldwide pandemic disease, Covid-19. In this case, the notion of self-preservation can be applied in a variety of ways. It can be done in three ways: medically, traditionally, and spiritually, by asking God for aid and protection at all times. The spiritual dimension is an inseparable approach in religion because practically everything that happens in the cosmos happens by God's will and permission. The virus is portrayed in religion as a disease that originates from God and is also sent down by God. As a result, the only way to avoid it is to engage in divine activities such as praying, repentance, and so on. 36

The exhortation to maintain oneself can be found in religious texts in several sources. There are at least three hadiths that describe the virus's presence and how to respond to it. Hafsah bint Sirin, Aisyah Ra, and Usamah Ra each recounted one of these hadiths. The following is one of the Hadith; "Thaun is a plague brought on by a group of Children of Israel or those who came before you. If you hear about it in a country, avoid going there. And if Thaun infects a country while you're there, don't leave to avoid being infected." Abu Nadr said, "Nothing should force you out except to prevent it" (Narrated by al-Bukhari). According to this Hadith, disease in the form of a plague is not a new occurrence in Islam. It has been documented since the Children of Israel were alive. The same goes for mitigation efforts in the event of an outbreak, such as the suggestion

33 Saifuddin Zuhri Qudsy and Ahmad Sholahuddin, "Kredibilitas Hadis dalam COVID19: Studi atas Bażl al-Mā'ūn fi Fadhli al-Thāun karya Ibnu Hajar al-Asqalany," AL QUDS: Jurnal Studi Alquran dan Hadis 4, no. 1 (May 11, 2020): 1.

${ }^{34}$ John Braverman, "Science and Faith: A New Introduction by John F. Haught," Theology Today 72 (July 1, 2015): 236-237.

${ }^{35}$ Qudsy and Sholahuddin, "Kredibilitas Hadis dalam COVID-19."

36 Abadi Wijaya, "Peran Agama Dalam Mengatasi Virus Corona," Www.UinMalang.Ac.Id, last modified April 20, 2020, accessed July 4, 2020, https://www.uinmalang.ac.id/blog/post/read/200401/peran-agama-dalam-mengatasi-virus-corona.html. 
to stay away from places contaminated with the outbreak and not to go out if your neighborhood has been exposed to the disease. If the foregoing explanation is applied to the modern world, the attitude of prudence and self-preservation, as expressed in several hadiths above, are all classic types of contemporary health protocols now being employed by the medical community to combat the spread of Covid19. The order not to leave the house, the recommendation to stay in the country, and the recommendation to avoid countries infected with the pandemic (virus/Tha'un) are all in line with health protocols that have been implemented by many countries, such as the policy of implementing social-physical distancing and minimizing activity in crowded places, including religious places. ${ }^{37}$

Efforts to overcome Covid-19 using a scientific method are more complex and systematic than religious approaches. Science, as one of the products of modernity, views Covid-19, which is currently wreaking havoc on the international community, not only as a virus that can damage health and cause death, but also as a threat to social stability in all areas, including politics, education, and the economy. ${ }^{38}$ As a result, the fight against Covid-19 must encompass not only physical rescue-though life safety is the most important factor - but also all social aspects. ${ }^{39}$ To get to this point, the use of science and its products is required. The utilization of scientific goods refers to the application of medical instruments and equipment, ranging from information and communication media to sophisticated technology to support and reinforce the Covid19 preventive program. In China, technology is used through the utilization of QuantUrban application and the Yi Kuang, or "Epidemic Situation" program. The local government can use this smartphone-based application to monitor and prevent the spread and transmission of Covid-19, including identifying and forecasting who comes into touch with people or Corona-positive patients. ${ }^{40}$

In addition to leveraging technology and information media, medical efforts can be used to handle Covid-19 from a scientific standpoint. Many individuals employ medical devices to cope with Covid-19 cases. ${ }^{41}$ In the medical approach, the Covid-19 mitigation process is carried out in various ways, particularly by promoting health protocol rules such as wearing masks, wearing personal protective equipment in the form of hand sanitizers, washing hands with soap, keeping a distance of 1-2 meters,

37 Mukharom and Aravik, "Kebijakan Nabi Muhammad Saw Menangani Wabah Penyakit Menular Dan Implementasinya Dalam Konteks Penanggulangan Coronavirus Covid19."

38 Liputan6.com, "Gara-Gara Corona, Penduduk Miskin Indonesia Naik Drastis," liputan6.com, last modified July 15, 2020, accessed July 15, 2020, https:/ / www.liputan6.com/bisnis/read/4305981/gara-gara-corona-penduduk-miskinindonesia-naik-drastis.

39 Muhammad Adnan Shereen et al., "Covid-19 Infection: Origin, Transmission, and Characteristics of Human Coronaviruses," Journal of Advanced Research 24 (July 2020): 91-98.

40 Brenda Goh, "Chinese Citizens Turn to Virus Tracker Apps to Avoid Infected Neighborhoods," Www.Reuters.Com, last modified Reuters, accessed August 15, 2021, https://www.reuters.com/article/us-china-health-apps-

idUSKBN1ZX2IH;\%20Reuters, \% 20“Chinese \% 20Citizens \%20Turn\%20to\%20Virus \% 20Tracker\%2 0Apps \%20to\%20Avoid\%20Infected\%20Neighborhoo; Reuters, "Chinese Citizens Turn to Virus Tracker Apps to Avoid Infected Neighborhoods," NBC News, last modified February 4, 2020, accessed August 15, 2021, https://www.nbcnews.com/tech/social-media/chinese-citizensturn-virus-tracker-apps-avoid-infected-neighborhoods-n1129111.

41 Kiesha Prem et al., "The Effect of Control Strategies to Reduce Social Mixing On Outcomes of the Covid-19 Epidemic in Wuhan, China: A Modelling Study," The Lancet Public Health 5, no. 5 (May 2020): e261-e270. 
avoiding crowds, and maintaining social distance. By implementing a thorough and long-term vaccination program, people can boost their body's immune system. ${ }^{42}$

\section{Vaccination as a Medical Instrument for the Covid-19 Mitigation}

With the growing global population and the rising social mobility of people who presently have cross-country-continental connectivity, focusing solely on social distancing measures would be insufficient to address Covid-19. From a medical standpoint, social separation will be beneficial if it is implemented in an area with a tightly regulated population, such as rural and remote areas in general. ${ }^{43}$ On the other hand, social distancing policy implementation will not be ideal in areas or regions with a high population density and activity mobility, such as urban areas. Even if compelled, it will jeopardize their socioeconomic survival. They will diminish their job productivity as a result of enforcing social distancing and tightening. ${ }^{44}$ As a result, alternative solutions from the medical community are required, one of which is mass vaccination. Vaccination will contribute to the strengthening of people's immune systems, allowing them to resume socioeconomic activities without fear of the Covid19 virus. ${ }^{45}$

In medical studies, vaccines are biological preparations that include antigens in the form of microorganisms and their components and/or substances produced from them, which have been processed in such a way through protracted and reliable research and experimental operations. Vaccines often include microorganisms, poisons, or substances that have been inactivated and/or turned off in some way. They have the unique function of forming immune power and producing antibodies to stimulate the immune system and protect it from disease or virus transmission. ${ }^{46}$ Medical workers usually administer the vaccination to groups of people categorized as infants or children, because that age group is thought to have a weak immune system. In certain situations, adults and the elderly are sometimes given vaccinations if they are in a scenario where they are in danger of transferring particular illnesses or viruses, such as the situation or threat of Covid-19 transmission that is presently engulfing the world population. According to research, someone who has been injected with the Sinovac vaccination will have a risk three times $(3 x)$ lower than persons who have not been vaccinated, based on clinical trials of the Sinovac vaccine. Meanwhile, according to Pfizer research trials, persons who were not vaccinated had a 20 times higher risk than those who had been vaccinated. 47

Vaccines are meant not only for prevention but also for preventative management

42 Lonergan and Chalmers, "Estimates of the Ongoing Need for Social Distancing and Control Measures Post-'Lockdown' from Trajectories Of Covid-19 Cases and Mortality."

43 Nora Azizah, "WHO: Social Distancing Saja Tak Cukup," Republika Online, last modified March 17, 2020, accessed July 2020, https:/ / republika.co.id/berita/q7bn3g463/who-emsocial-distancingem-saja-tak-cukup.

44 Insi Nantika Jelita, "Ombudsman: Social Distancing Kurang Efektif, Lakukan Evaluasi," Media Indonesia, last modified April 7, 2020, accessed July 15, 2020, https://mediaindonesia.com/read/detail/301999-ombudsman-social-distancing-kurangefektif-lakukan-evaluasi.

45 Tamam El-Elimat et al., "Acceptance and Attitudes toward COVID-19 Vaccines: A Cross-Sectional Study from Jordan," PLOS ONE 16, no. 4 (April 23, 2021): e0250555.

${ }^{46} \mathrm{Xu}$ Keyue and Leng Shumei, "Vaccines Stay Effective in Reducing Symptoms in DeltaHit Indonesia: Sinovac," Www.Globaltimes.Cn, last modified June 22, 2021, accessed August 15, 2021, https:/ / www.globaltimes.cn/page/202106/1226825.shtml.

47 Ibid. 
while dealing with Covid-19. Vaccination serves at least four purposes: 1) Reducing Covid-19-related morbidity and mortality; 2) Functioning as Medical efforts to achieve a level of herd immunity that will help prevent transmission (herd immunity); 3) Maintaining or protecting public health as a whole; 4) Maintaining productivity and minimizing social impacts that may experience a crisis as a result of Covid-19's spread, including economic, political, and educational impacts. Vaccines serve as effectiveness or prevention rather than as medications. ${ }^{48}$ This indicates that if a person has been vaccinated, their chance of infection is lower than if they have never been vaccinated. It's crucial to note that, although the Covid-19 vaccine has an efficacy function, not all vaccinations have the same amount of efficacy. Sinovac, for example, has a 78 percent efficacy rating, whereas Moderna has a 94.5 percent rating, Astra Zeneca has a 90 percent rating, and Pfizer has a 95 percent rating. ${ }^{49}$ Despite using the same type of vaccination, each country has different levels of effectiveness. In the case of the Sinovac vaccine, for example, three nations have utilized it: Turkey, Brazil, Chile, and Indonesia. Sinovac has a 91 percent efficacy value in Turkey, 78 percent in Brazil, and 65.3 percent in Indonesia when it comes to prevent Covid-19 transmission. 50

In terms of vaccination, a lot of developed countries have required it for all residents. Several nations, such as the United Kingdom and Singapore, make vaccination a legal necessity for citizens to engage in activities outside the home. Those who have been vaccinated will receive a certificate with a unique barcode that they can use to go outside later. A number of countries' mass vaccination initiatives have been demonstrated to be effective. Some nations that were previously eager to implement mass vaccination, such as the United Kingdom, China, and Denmark, are now easing social restrictions, such as permitting public events and repealing the requirement to wear masks. ${ }^{51}$

Even though medical attempts to eradicate Covid-19 by vaccination have been effective, it is not easy to execute in all nations. In truth, many people experience anxiety or even resistance in a variety of situations. In Indonesia, vaccination rejection is relatively high, and it usually occurs under the pretext of religion. In this case, according to a survey conducted by the Ministry of Religion's Research and

48 Alexandre de Figueiredo et al., "Mapping Global Trends in Vaccine Confidence and Investigating Barriers to Vaccine Uptake: A Large-Scale Retrospective Temporal Modelling Study," The Lancet 396, no. 10255 (September 26, 2020): 898-908.

49 CDC, "Information about the Pfizer-BioNTech COVID-19 Vaccine," Centers for Disease Control and Prevention, last modified June 24, 2021, accessed August 15, 2021, https:/ / www.cdc.gov/coronavirus/2019-ncov/vaccines/different-vaccines/Pfizer-

BioNTech.html; Australian Government Department of Health, "About the Pfizer/BioNTech COVID-19 Vaccine," Text, Australian Government Department of Health (Australian Government Department of Health, January 24, 2021), last modified January 24, 2021, accessed August 15, 2021, https://www.health.gov.au/initiatives-and-programs/covid-19-vaccines/learn-aboutcovid-19-vaccines/about-the-pfizerbiontech-covid-19-vaccine.

50 WHO, "WHO Validates Sinovac Covid-19 Vaccine For Emergency Use and Issues Interim Policy Recommendations," Www.Who.Int, last modified June 1, 2021, accessed August 15, 2021, https://www.who.int/news/item/01-06-2021-who-validates-sinovac-covid-19vaccine-for-emergency-use-and-issues-interim-policy-recommendations.

51 Alex Kleiderman, “Covid: Mask Law and One Metre Rule Set to End in England," BBC News, July 5, 2021, sec. UK, accessed August 15, 2021, https://www.bbc.com/news/uk57715496; Laurel Wamsley, "England Has Lifted Most Of Its COVID-19 Restrictions, Even As U.K. Cases Are Up 41\%," NPR, July 19, 2021, sec. The Coronavirus Crisis, accessed August 15, 2021, https://www.npr.org/sections/coronavirus-liveupdates/2021/07/19/1017877573/england-has-lifted-most-of-its-covid-19-restrictions. 
Development Center in December 2020, 57.66 percent of 2,610 respondents from 34 provinces in Indonesia refused vaccination due to religious considerations, particularly regarding the halal status of vaccines because they believe that vaccines are made of substances or ingredients that are prohibited by religion. ${ }^{52}$

\section{E. Religious Views on the COVID-19 Vaccination}

Amid the Covid-19 vaccine acceleration program, the question of its safety frequently emerges. It's reasonable, considering that there are a lot of information about the risks of vaccinations that have spread on the internet. Medically, based on clinical studies, there have been no research findings that establish the occurrence of acute to life-threatening adverse effects in Sinovac, Moderna, Pfizer, and AstraZeneca vaccines. Pain, discomfort, swelling, weakness, and tiredness are the most frequent vaccination effects following injection. ${ }^{53}$ Aside from the safety aspect, another question that frequently arises is the halal ingredient. In Indonesia, vaccinations are evaluated not only for their efficiency and effectiveness, but also for their halal status, which is determined by the content of the components or substances, the production method, and the facilities utilized. The key question today is: what is the true religious perspective on Covid-19 vaccination amid the ongoing controversy and speculation about the vaccine's safety and halal status in the public? Before answering this topic, it's necessary to explain how religion views disease in general.

As previously stated, Islam divides the disease into three categories: disease as a life challenge, disease based on past deeds, and disease that results in death. ${ }^{54}$ The first two classes of diseases come under the category of diseases that can still be cured utilizing traditional, spiritual, or current scientific approaches, such as medical equipment. In the religious context, the justifications for disease in Islam can be found in a variety of sources, including the hadith and the Qur'an. At least three hadiths mention disease, one of which is narrated by Abu Dawud: "Allah has brought down sickness and medicine, and provided a remedy for every ailment; So seek therapy, and do not seek treatment with illegal things." (Narrated by Abu Dawud from Abu Darda). As for in the Qur'an, the discussion of the disease can be found in many passages, one of which is: "O humanity! Indeed, there has come to you a warning from your Lord, a cure for what is in the hearts, a guide, and a mercy for the believers"(QS. Yunus: 57).

There are at least two major points that can be drawn from the above explanation if you look at it more closely: First, according to Islam, every disease suffered by people does not emerge independently with no cause, but it rather arises at the will of God through specific rules of causality (cause and effect); Second, every sickness that affects humans has its own treatment. It means that no ailment cannot be healed; it only requires people's effort to discover a treatment; Third, humans' endeavor to heal is a command, which means a suggestion or even a need. In another word, therapy for

52 Dewi Indah Ayu, "Survei Litbang Kemenag, Mayoritas Umat Patuhi SE Panduan Ibadah Ramadan Kementrian Agama RI," https://kemenag.go.id/, last modified Mei 2021, accessed August 15, 2021, https://kemenag.go.id/read/survei-litbang-kemenag-mayoritasumat-patuhi-se-panduan-ibadah-ramadan.

53 "COVID-19: Vaccine Side Effects and Reactions," Ministry of Health NZ, last modified August 12, 2021, accessed August 15, 2021, https://www.health.govt.nz/our-work/diseasesand-conditions/covid-19-novel-coronavirus/covid-19-vaccines/covid-19-vaccine-side-effectsand-reactions; CDC, "What to Expect after Getting a COVID-19 Vaccine," Centers for Disease Control and Prevention, last modified August 6, 2021, accessed August 15, 2021, https://www.cdc.gov/coronavirus/2019-ncov/vaccines/expect/after.html.

${ }^{54}$ Attum et al., "Cultural Competence in the Care of Muslim Patients and Their Families." 
certain ailments is a part of sunnatullah. In connection with this, Agung Sasongko writes in his book Getting to Know the Medical System in Islam (2018) that there are three types of therapy in Islam: 1) Spiritual: This strategy focuses on enhancing the soul's mindset; 2) Preventive, or prevention-based therapy strategies. ${ }^{55}$ In his book "At-Tibb An-Nabawi: Methods of Medicine of the Prophet SAW, he explained that preventive techniques are the embodiment of the medical world, such as maintaining diet, exercise, and quarantine treatment for plague sufferers; and 3) Curative, namely remedy through treatment. The last two terms (preventive and curative) refer to medical procedures that are currently being developed. In the context of this study, one of the aforesaid therapeutic and preventative therapy measures is what we now know as a vaccination, which is now being employed by the medical community to fight Covid-19.56

In light of the foregoing, it can be argued that there is no epistemological contradiction between religion and vaccine treatment, including the Covid-19 vaccine. Yusuf Qardhawy, the world's greatest scholar and a mujtahid based in Qatar, also approves the vaccination. Outside of Islam, similar views can also be seen in other religions. ${ }^{57}$ For example, the Catholic Church's leadership and, at the same time, Pope Francis, the Vatican's head of state, called for vaccination among Christians. In the case of Hindus, the General Chair of Parisada Hindu Dharma Indonesia (PHDI), Wisnu Bawa Tenaya, called to Hindus to participate in the government's Covid-19 immunization campaign. ${ }^{58}$ Vaccines have been used by the medical community in Indonesia for a long time. The authorities, notably the Indonesian Ulema Council (MUI), have given clearance for its usage. This can be found in the MUI decree number 4 on vaccination, which was issued in 2016. Similarly, MUI issued a decree in response to the Covid-19 vaccine, declaring in letter No. 02 of 2021 that the use of vaccines - in this case, the Sinovac vaccine - that are intended to protect the body from virus transmission is permissible in Islam as long as the materials and substances used are holy and lawful. ${ }^{59}$

Based on the results of an audit by the LPPOM MUI Auditor Team on one of the Covid-19 vaccine products, in this case, Sinovac Life Sciences Co. Ltd. China and PT. Bio Farma (Persero) regarding the production process and materials, which are critical points of vaccine manufacture, the MUI concluded that the substances contained in it are considered halal.

This is due to the fact that it does not use any unclean (najis) or haram elements as defined by Shari'a, such as pork or materials contaminated with pigs and their derivatives (intifa'), does not use human body parts (juz'minal insan), and does not

\footnotetext{
55 Agung Sasongko, "Mengenal Sistem Pengobatan Dalam Islam," Republika.co.Id, last modified Oktober 201AD, accessed August 15, 2021, https:// www.republika.co.id/berita/pfyq8h313/mengenal-sistem-pengobatan-dalam-islam.

${ }^{56}$ Ibnu Qayyim Al-Jauziyyah, At-Tibb An-Nabawi Metode Pengobatan Nabi SAW (Jakarta: Griya Ilmu, 2004).

${ }^{57}$ Muhammad Mahmud Nasution, "Vaksinasi dalam Perspektif Islam," Forum Paedagogik 10, no. 2 (September 28, 2020): 61-70.

58 Kompas Cyber Media, "PHDI Imbau Umat Hindu Ikuti Program Vaksinasi Covid-19," KOMPAS.com, last modified March 12, 2021, accessed August 15, 2021, https:// nasional.kompas.com/read/2021/03/12/10545201/phdi-imbau-umat-hindu-ikutiprogram-vaksinasi-covid-19.

${ }^{59}$ MUI, "Fatwa Majelis Ulama Indonesia Nomor : 02 Tahun 2021tentang Produk Vaksin Covid-19 Dari Sinovac Life Sciences Co. Ltd. China Dan PT. Bio Farma (Persero)" (Majelis Ulama Indonesia, January 11, 2021).
} 
come into contact with any unclean (najis) objects, resulting in mutanajjis. However, the purification has been done under Syariah purification guidelines (tathhir syar'i), and it was also done in sanctified manufacturing facilities that are exclusively used for Covid19 vaccination products. 60

\section{F. The Function of Vaccination Benefit; Overview of Social Theology and Science}

The term theology is synonymous with the discussion of a religion's core or major doctrines in a broad sense. From an etymological standpoint, theology is derived from two words: theos, which means God, and logos, which means science; hence, theology refers to God's science in all of its aspects. ${ }^{61}$ Theology is defined as a discipline that studies God and His relationship with the reality of the world in terms of terminology. Theology is regarded as one of the areas of current philosophy in the academic world, namely a field that addresses God epistemologically. The term "theology" in Islam refers to the science of God's oneness ('ilm altauh), which alludes to the existence of the only one God.62

Religion, according to the Islamic perspective, refers to one's absolute awareness of God's presence, which subsequently imprints as a justification and firm belief in the heart (faith). Self-realization is the pinnacle of one's religion, which involves integrating abstract or metaphysical religious ideals and teachings into empirical conceptions and experiences in everyday life, which encompass all social and ritual acts. The intellectual endeavor to position the anthropocentrism dimension within the sphere of metaphysical theology is a philosophical endeavor to convert religion from its metaphysical origin into practical life. As a result of this interpretation, social theology is fundamentally a theological form that attempts to reconcile the transcendent and anthropocentric dimensions of religion.63 Simply said, social theology is a theological worldview that balances the servant side and the human kingdom in a complementary and interconnected manner. ${ }^{64}$

Based on this social theological theory, the function and duty of a servant cannot be separated from the social reality and changes that surround him. At the same time, theological principles necessitate that the human caliphate plays a significant role and function in realizing divine values in everyday life. The dignity of the caliphate and servanthood as religious people includes maintaining and caring for the natural environment, preserving and avoiding any devastation, and upholding the basic rights of everyone such as the right to live, obtain comfort and tranquility, as well as the right to be protected from all types of dangers and diseases. ${ }^{65}$ In the context of Islamic teachings, Abu Ishiq al-Syathibi (in Miatul Qudsia, 2019) refers the concept of social

${ }^{60}$ Abdul Muiz Ali, “Telaah Vaksinasi : Dari Sejarah Hingga Hukumnya," Majelis Ulama Indonesia, January 18, 2021, accessed August 15, 2021, https://mui.or.id/pojokmui/29471/telaah-vaksinasi-dari-sejarah-hingga-hukumnya/.

${ }^{61}$ Febri Hijroh Mukhlis, “Model Penelitian Kalam; Teologi Islam (Ilmu Kalam) Ahmad Hanafi" (2015): 12.

62 Hannan and Muhaimin, "Teologi Kemaslahatan Social-Phsycal Distancing dalam Penanggulangan Covid-19."

${ }^{63}$ Muhammad Said, "Paradigma Teologi Sosial: Revitalisasi Fungsi Teologi Islam dalam Konteks Multikultural," Jurnal Al-Irfani 3, no. 1 (n.d.): 46.

${ }^{64}$ Alwi Bani Rakhman, "Teologi Sosial; Keniscayaan Keberagamaan yang Islami Berbasis Kemanusiaan," ESENSIA: Jurnal Ilmu-Ilmu Ushuluddin 14, no. 2 (October 22, 2013): 161.

${ }^{65}$ Muhaemin Latif, "Membumikan Teologi Islam dalam Kehidupan Modern (Berkaca dari Mohammed Arkoun)," Jurnal Dakwah Tabligh 14, no. 2 (2013): 13; Anisa Listiana, "Teologi Sosial Masyarakat Pinggiran," PALASTREN 11, no. 2 (2018): 20. 
theology to a theory of maqasid al-syari'ah, which states that the purpose or objectives of religious law stipulation must be oriented toward five things: maintaining religion, soul, mind, lineage, and property. ${ }^{66}$

One of the five primary sharia principles is to preserve one's own health. The notion of self-preservation entails safeguarding against anything harmful, lifethreatening, or attracts sickness, as well as anything that poses a bodily or mental risk.67 In its practice, the Islamic concept to look after oneself (hifzu al-Nafs) has a universal connotation. It can be interpreted in many different ways. It depends on the social situation that occurred at the time. It can be done in a variety of ways, including medical, traditional, and spiritual approaches, as many Sufists did. A vaccine often called immunization in various languages is one of the instruments for selfpreservation in a scientific method. Vaccination is one of the medical measures ( $\mathrm{min}$ Babi ath-Thibbi al-Wiqoi) that has the specific aim of preventing and protecting oneself from developing illnesses and transferring viruses in this context. 68

So far, no religion has mentioned vaccination in its teachings, yet this does not indicate that vaccinations are prohibited or outlawed. Vaccines can be viewed as the result of scientists' ijtihad as an effort to create medicinal products. The main objective is to increase and enhance the immune system. As a result, it can protect the body from illness assaults or transmission, whether those diseases are caused by bacteria or viruses. Vaccines have been recognized and utilized for a long time in the field of medicine. There were other vaccinations long before the Covid-19 vaccine, including the meningitis vaccine, measles vaccine, smallpox vaccine, hepatitis vaccine, and many more. If the function of immune-strengthening in the vaccination program (Covid-19) is related to Abu Ishiq Syathibi's al-maqasid al-syari'ah theory, it certainly has strong relevance to the preventive principle (hifzu al-Nafs) as taught by Islam, where the preventive function is not only aimed at protecting oneself personally but also for the social benefit as a whole. 69

According to Wafi Muhamin's (2020) interpretation, the religious and scientific benefits of preventative vaccination can be understood from three perspectives: coverage, argument, and influence. ${ }^{70}$ In terms of coverage, vaccination efforts are designed to safeguard the population from the threat of epidemic diseases, where the risk of an outbreak is not only personal but universal. When one individual gets infected, everyone in his immediate vicinity is at risk. As a result, conquering Covid-19 is no longer about offering maslahah to individuals (partial/juziyah), but rather about giving maslahah to collectivities because it includes the safety of many people's lives (communal/kulliyah). From a scientific standpoint, the overall advantage will only be recognized if the community has reached the level of herd immunity, which can only

66 Miatul Qudsia, "Maqashid Syariah Sebagai Basis Fiqih Tranformatif Untuk Peningkatan Kualitas Komunitas Petani," last modified Oktober 2019, accessed July 15, 2020, https:// www.nu.or.id/post/read/112434/maqashid-syariah-sebagai-basis-fiqih-tranformatifuntuk-peningkatan-kualitas-komunitas-petani.

67 Abdurrahman Kasdi, “Maqasyid Syari'ah Perspektif Pemikiran Imam Syatibi Dalam Kitab Al-Muwafaqat," YUDISIA 5, no. 1 (June 2014).

68 Muiz Ali, "Telaah Vaksinasi."

${ }^{69}$ Ali Mutakin, “Teori Maqâshid Al Syarî’ah dan Hubungannya dengan Metode Istinbath Hukum," Kanun Jurnal Ilmu Hukum 19, no. 3 (Agustus 2017): 24.

70 Abd Hannan and Wafi Muhaimin, 'Teologi Kemaslahatan Social-Phsycal Distancing dalam Penanggulangan Covid-19', Kuriositas; Media Komunikasi Sosial dan Keagamaan 13, no. 1 (June 2020): 78-102; Lihat juga Abd Hannan and Heny Triyaningsih, 'Mitigasi Covid-19 melalui Kearifan Lokal Pesantren di Madura' 6 (2020): 30. 
be attained if the vaccination program is effectively implemented. In terms of its influence, vaccination is designed to safeguard and satisfy the necessities of human existence, particularly those related to mental and physical safety, as well as to keep people safe from illness caused by the spread of malignant epidemic illnesses. Similarly, in terms of the strength of the argument, the aspect of benefit of the Covid-19 vaccine can be found in the strong theological foundation that derives explicitly from the hadith and the Qur'an, both historical and textual.

Thus, science and religion play their own roles in dealing with the Covid19 pandemic. Religious perspective plays a greater portion in bolstering the justifications for the legislation of Covid19 vaccination based on the standpoint of jurisprudence and sharia. Meanwhile, science, through its technical and medical products, serves more as a tool for demonstrating how the notion of self-preservation (hifzu al-Nafs) should be applied in everyday life so that it can subsequently create conformity with the existing social environment at the practical level. Even if science today interprets the notion of self-preservation (hifzu al-Nafs) in various forms and ways, such as vaccination, this does not imply that science is anti-religion. Rather, it's a logical result of the growing complexity of today's societal problems, which are continually changing and evolving.

\section{G. Conclusion}

This essay concludes with three major points: First, the Covid-19 virus continues to pose a major threat to the global population. Even though various nations throughout the world have established health protocol measures such as socialpsychological distance and constraining social activities, as well as the implementation of regional quarantine (lockdown), Covid-19 has yet to be contained. Several nations, on the other hand, reported new cases in the form of novel variations originating from changes of prior viruses. The ever-increasing uncertainty over Covid-19 has prompted global countries to act rapidly, one of which is mass vaccination of the population, which will establish herd immunity afterward. With herd immunity, there is hope that they will have a decreased chance of transmission, allowing them to defend themselves from danger while also bringing goodness and benefit to others around them; Second, if the vaccine function is included in Islamic theology, the concepts of goodness and benefit in vaccination implementation have the same substance as social theological principles. The term "social theology" is used in this study to describe the various dimensions of benefit found in the maqashid al-syari'ah theory, which states that the purpose or objectives of the application of religious law (Islam) must be oriented toward five things, one of which is the protection of the soul or spirit or selfpreservation (hifzu al-Nafs). Attempts to deal with Covid-19 by injecting vaccines into the body are thus simply another type of self-preservation (hifzu al-Nafs). Vaccines work by boosting the immune system of the body, allowing it to protect its users against disease or virus transmission; Third, regarding the advantages of vaccination, the religious perspective is more important in explaining the justifications for the halal status of Covid-19 vaccine from the perspective of law and sharia. Based on its strong and obvious reasons, including historical and textual considerations, religion validates the legislation that vaccinations are permitted. In terms of science's perspective, medical products such as vaccination play a crucial role in demonstrating how the notion of self-preservation (hifzu al-Nafs) should be used in daily life. Thus, vaccination can be considered one of science's true contributions to the transformation of religious values and teachings from abstract or conceptual to tangible ideas and experiences. 


\section{H. Acknowledgments}

The author would like to thank everyone involved from beginning to end of the process. This includes our peers who provide feedback, as well as the editorial and review team who handled the manuscript and provided valuable insights to improve it further. We would also like to thank all the administrators of the research and service institutions on our campus, who have supported this research process, both in terms of material and moral support.

\section{Author Contributions Statement}

$\mathrm{AH}$ played a major role in designing, conceptualizing, and leading the project. ZS contributes in terms of searching data, preparing data, and analyzing data. Meanwhile, KAMY contributed to editing and translating the manuscript[.]

\section{REFERENCES}

Al-Asqalany, Ibn Hajar. Bażl Al-Mā'ūn Fi Faḍ Li al-T ā'ūn. (Riyadh: Dār al-Ashimah, 1991.

Al-Jauziyyah, Ibnu Qayyim. At-Tibb An-Nabawi Metode Pengobatan Nabi SAW. Jakarta: Griya Ilmu, 2004.

Antonelli, Michela, Rose S Penfold, Jordi Merino, Carole H Sudre, Erika Molteni, Sarah Berry, Liane S Canas, et al. "Risk Factors And Disease Profile Ff Post-Vaccination Sars-Cov-2 Infection in UK Users of the Covid Symptom Study App: A Prospective, Community-Based, Nested, Case-Control Study." The Lancet Infectious Diseases (n.d.). Accessed October 21, 2021. https:// doi.org/10.1016/S1473-3099(21)00460-6.

Attum, Basem, Sumaiya Hafiz, Ahmad Malik, and Zafar Shamoon. "Cultural Competence in the Care of Muslim Patients and Their Families." In StatPearls. Treasure Island (FL): StatPearls Publishing, 2020. Accessed July 15, 2020. http://www.ncbi.nlm.nih.gov/books/NBK499933/.

Azizah, Nora. "WHO: Social Distancing Saja Tak Cukup." Republika Online. Last modified March 17, 2020. Accessed July 4, 2020. https:// republika.co.id/berita/q7bn3g463/who-emsocial-distancingem-saja-takcukup.

Balitbangdiklat Kemenag. "Respon Dan Kesiapan Umat Beragama Atas Rencana Vaksinasi Covid-19." Balitbangdiklat.Kemenag.Go.Id. Last modified January 13, 2021. Accessed August 15, 2021. https:// balitbangdiklat.kemenag.go.id/berita/respon-dan-kesiapan-umatberagama-atas-rencana-vaksinasi-covid-19.

Banerji, Aleena, Anna R. Wolfson, Paige G. Wickner, Amelia S. Cogan, Aubree E. McMahon, Rebecca Saff, Lacey B. Robinson, Elizabeth Phillips, and Kimberly G. Blumenthal. "COVID-19 Vaccination in Patients with Reported Allergic Reactions: Updated Evidence and Suggested Approach." The Journal of Allergy and Clinical Immunology: In Practice 9, no. 6 (June 1, 2021): 2135-2138.

Barret, Amy. "Lambda Covid Variant: All You Need to Know About The New UK Coronavirus Strain." BBC Science Focus Magazine. Last modified August 9, 2021. Accessed August 15, 2021. https://www.sciencefocus.com/news/lambdavariant/. 
Barret, Amy. "Lambda Covid Variant: All You Need to Know About The New UK Coronavirus Strain." BBC Science Focus Magazine. Accessed August 15, 2021. https://www.sciencefocus.com/news/lambda-variant/.

Boudjelal, Mohamed, Faisal Almajed, Ahmed M. Salman, Naif K. Alharbi, Margaretta Colangelo, Julia M. Michelotti, Gene Olinger, Mariwan Baker, Adrian V.S. Hill, and Ahmed Alaskar. "Covid-19 Vaccines: Global Challenges and Prospects Forum Recommendations." International Journal of Infectious Diseases 105 (April 1, 2021): 448-451.

Braverman, John. "Science and Faith: A New Introduction by John F. Haught." Theology Today 72 (July 1, 2015): 236-237.

Campbell, Heidi A., and Zachary Sheldon. "Religious Responses to Social Distancing Revealed through Memes during the COVID-19 Pandemic." Religions 12, no. 9 (2021).

CDC. "Information about the Pfizer-BioNTech COVID-19 Vaccine." Centers for Disease Control and Prevention. Last modified June 24, 2021. Accessed August 15, 2021. https://www.cdc.gov/coronavirus/2019-ncov/vaccines/differentvaccines/Pfizer-BioNTech.html.

CDC. "What to Expect after Getting a COVID-19 Vaccine." Centers for Disease Control and Prevention. Last modified August 6, 2021. Accessed August 15, 2021. https://www.cdc.gov/coronavirus/2019-ncov/vaccines/expect/after.html.

Cucunawangsih, Cucunawangsih, Ratna Sari Wijaya, Nata Pratama Hardjo Lugito, and Ivet Suriapranata. "Post-Vaccination Cases of COVID-19 among Healthcare Workers at Siloam Teaching Hospital, Indonesia." International Journal of Infectious Diseases 107 (June 1, 2021): 268-270.

Cui, Jie, Fang Li, and Zheng-Li Shi. "Origin and Evolution of Pathogenic Coronaviruses." Nature Reviews Microbiology 17, no. 3 (March 2019): 181-192.

El-Elimat, Tamam, Mahmoud M. AbuAlSamen, Basima A. Almomani, Nour A. AlSawalha, and Feras Q. Alali. "Acceptance and Attitudes toward COVID-19 Vaccines: A Cross-Sectional Study from Jordan." PLOS ONE 16, no. 4 (April 23, 2021): e0250555.

Fasya, Teuku Kemal. "Covid-19 dan Dekonstruksi Teologis." Media Indonesia. Last modified April 3, 2020. Accessed July 15, 2020. https:// mediaindonesia.com/read/detail/300915-covid-19-dan-dekonstruksiteologis.

de Figueiredo, Alexandre, Clarissa Simas, Emilie Karafillakis, Pauline Paterson, and Heidi J Larson. "Mapping Global Trends in Vaccine Confidence and Investigating Barriers to Vaccine Uptake: A Large-Scale Retrospective Temporal Modelling Study." The Lancet 396, no. 10255 (September 26, 2020): 898-908.

Galang, Joseph Renus F. "Science and Religion for Covid-19 Vaccine Promotion." Journal of public health (Oxford, England) 43, no. 3 (September 22, 2021): e513-e514.

Goh, Brenda. "Chinese Citizens Turn to Virus Tracker Apps to Avoid Infected Neighborhoods." Www.Reuters.Com. Last modified Reuters. Accessed August 15, 2021. https://www.reuters.com/article/us-china-health-apps-idUSKBN1ZX2IH.

Hagen, Ashley. "How Dangerous Is the Delta Variant (b.1.617.2)?" ASM.Org. Last modified July 30, 2021. Accessed August 15, 2021. https://asm.org/Articles/2021/July/How-Dangerous-is-the-Delta-Variant-B-1617-2.

Hannan, Abd, Siti Azizah, and Husna Atiya. “Dinamika Pesantren Dalam Merespons Pandemi Covid-19 Di Madura." DINIKA : Academic Journal of Islamic Studies 5, no. 
http:/ / ejournal.iainsurakarta.ac.id/index.php/dinika/article/view/2923.

Hannan, Abd, and Wafi Muhaimin. "Teologi Kemaslahatan Social-Phsycal Distancing dalam Penanggulangan Covid-19." KURIOSITAS; Media Komunikasi Sosial dan Keagamaan 13, no. 1 (June 2020): 78-102.

Hannan, Abd, Fithriyah Rahmawati, and Ahmad Imam Khairi. "The Moderatism and Religious Conservatism Problems in the Middle of Covid-19 Pandemic Era" 13 (n.d.): 31.

Hannan, Abd, and Heny Triyaningsih. "Mitigasi Covid-19 melalui Kearifan Lokal Pesantren di Madura" 6 (2020): 30.

Health, Australian Government Department of. "About the Pfizer/BioNTech COVID19 Vaccine." Text. Australian Government Department of Health. Australian Government Department of Health, January 24, 2021. Last modified January 24, 2021. Accessed August 15, 2021. https://www.health.gov.au/initiatives-andprograms/covid-19-vaccines/learn-about-covid-19-vaccines/about-thepfizerbiontech-covid-19-vaccine.

Hilmy, Masdar. "Sikap Ilmiah Menghadapi Pandemi Covid-19." Kolom UINSA, April 4, 2020. Accessed July 4, 2020. https://w3.uinsby.ac.id/sikap-ilmiah-menghadapipandemi-covid-19/.

Hilmy, Masdar, and Khoirun Niam. "Winning the Battle of Authorities: The Muslim Disputes Over the Covid-19 Pandemic Plague in Contemporary Indonesia." QIJIS (Qudus International Journal of Islamic Studies) 8, no. 2 (December 31, 2020): 293.

Hurst, Tara. "Covid: Lambda Variant Is Now In 29 Countries, But What Evidence Do We Have That It's More Dangerous?" The Conversation. Last modified July 12, 2021. Accessed August 15, 2021. http://theconversation.com/covid-lambdavariant-is-now-in-29-countries-but-what-evidence-do-we-have-that-its-moredangerous-163936.

Ichsan, A.Syalaby. "Tiga Hadist tentang Thaun yang Mesti Anda Ketahui." Republika Online. Last modified April 11, 2020. Accessed July 15, 2020. https:// republika.co.id/share/q8mbkw483.

Indah Ayu, Dewi. "Survei Litbang Kemenag, Mayoritas Umat Patuhi SE Panduan Ibadah Ramadan Kementrian Agama RI." https://kemenag.go.id/. Last modified Mei 2021. Accessed August 15, 2021. https://kemenag.go.id/read/surveilitbang-kemenag-mayoritas-umat-patuhi-se-panduan-ibadah-ramadan.

Jelita, Insi Nantika. “Ombudsman: Social Distancing Kurang Efektif, Lakukan Evaluasi." Media Indonesia. Last modified April 7, 2020. Accessed July 15, 2020. https:// mediaindonesia.com/read/detail/301999-ombudsman-socialdistancing-kurang-efektif-lakukan-evaluasi.

Jennings, Will, Gerry Stoker, Hannah Bunting, Viktor O. Valgarðsson, Jennifer Gaskell, Daniel Devine, Lawrence McKay, and Melinda C. Mills. "Lack of Trust, Conspiracy Beliefs, and Social Media Use Predict COVID-19 Vaccine Hesitancy." Vaccines 9, no. 6 (2021).

Kasdi, Abdurrahman. "Maqasyid Syari'ah Perspektif Pemikiran Imam Syatibi Dalam Kitab Al-Muwafaqat." YUDISIA 5, no. 1 (June 2014).

Keyue, $\mathrm{Xu}$, and Leng Shumei. "Vaccines Stay Effective in Reducing Symptoms in Delta-Hit Indonesia: Sinovac." Www.Globaltimes.Cn. Last modified June 22, 2021. $\begin{array}{lll}\text { Accessed } & \text { August } & 2021 .\end{array}$ https:// www.globaltimes.cn/page/202106/1226825.shtml. 
Kleiderman, Alex. "Covid: Mask Law and One Metre Rule Set to End in England." BBC News, July 5, 2021, sec. UK. Accessed August 15, 2021. https://www.bbc.com/news/uk-57715496.

Latif, Muhaemin. "Membumikan Teologi Islam dalam Kehidupan Modern (Berkaca dari Mohammed Arkoun)." Jurnal Dakwah Tabligh 14, no. 2 (2013): 13.

Li, Qun, Xuhua Guan, Peng Wu, Xiaoye Wang, Lei Zhou, Yeqing Tong, Ruiqi Ren, et al. "Early Transmission Dynamics in Wuhan, China, of Novel CoronavirusInfected Pneumonia." New England Journal of Medicine 382, no. 13 (March 26, 2020): 1199-1207.

Liputan6.com. "Gara-Gara Corona, Penduduk Miskin Indonesia Naik Drastis." liputan6.com. Last modified July 15, 2020. Accessed July 15, 2020. https://www.liputan6.com/bisnis/read/4305981/gara-gara-corona-pendudukmiskin-indonesia-naik-drastis.

Listiana, Anisa. “Teologi Sosial Masyarakat Pinggiran.” PALASTREN 11, no. 2 (2018): 20.

Lonergan, Mike, and James D. Chalmers. "Estimates of the Ongoing Need for Social Distancing and Control Measures Post-'Lockdown' from Trajectories Of Covid-19 Cases and Mortality." European Respiratory Journal 31, no. 2 (June 1, 2020): 2001483.

Media, Kompas Cyber. "PHDI Imbau Umat Hindu Ikuti Program Vaksinasi Covid-19." KOMPAS.com. Last modified March 12, 2021. Accessed August 15, 2021. https://nasional.kompas.com/read/2021/03/12/10545201/phdi-imbau-umathindu-ikuti-program-vaksinasi-covid-19.

Muarif, Ahmad Syamsul, and Mohammad Yunus. "Tinjauan Teologi Islam di Dunia: 'Isu dan Prospek' Frederick Mathewson Denny." Jurnal Islamika: Jurnal Ilmu-Ilmu Keislaman 19, no. 02 (2019): 14.

MUI. "Fatwa Majelis Ulama Indonesia Nomor : 02 Tahun 2021tentang Produk Vaksin Covid-19 Dari Sinovac Life Sciences Co. Ltd. China Dan PT. Bio Farma (Persero)." Majelis Ulama Indonesia, January 11, 2021.

Muiz Ali, Abdul. "Telaah Vaksinasi : Dari Sejarah Hingga Hukumnya." Majelis Ulama Indonesia, January 18, 2021. Accessed August 15, 2021. https://mui.or.id/pojokmui/29471/telaah-vaksinasi-dari-sejarah-hingga-hukumnya/.

Mukharom, Mukharom, and Havis Aravik. "Kebijakan Nabi Muhammad Saw Menangani Wabah Penyakit Menular Dan Implementasinya Dalam Konteks Penanggulangan Coronavirus Covid-19." SALAM: Jurnal Sosial dan Budaya Syar-i 7, no. 2 (March 24, 2020).

Mukhlis, Febri Hijroh. "Model Penelitian Kalam; Teologi Islam (Ilmu Kalam) Ahmad Hanafi" (n.d.): 12.

Munastiwi, Erni, and Siti Marfuah. "The Influence of Assignment Methods on the Development Aspects of Religious and Moral Values of Early Childhood During the Covid-19 Pandemic." Akademika: Jurnal Pemikiran Islam (online); Vol 26 No 1 (2021) (May 24, 2021). https://ejournal.metrouniv.ac.id/index.php/akademika/article/view/3143.

Mutakin, Ali. “Teori Maqâshid Al Syarî̀ah dan Hubungannya dengan Metode Istinbath Hukum." Kanun Jurnal Ilmu Hukum 19, no. 3 (Agustus 2017): 24.

Nasution, Muhammad Mahmud. "Vaksinasi dalam Perspektif Islam." Forum Paedagogik 10, no. 2 (September 28, 2020): 61-70.

Pandey, Vikas. "Delta Plus Variant: Can India Prevent Third Covid Wave?" BBC News, June 24, 2021, sec. India. Accessed August 15, 2021. https://www.bbc.com/news/world-asia-india-57577138. 
Prem, Kiesha, Yang Liu, Timothy W Russell, Adam J Kucharski, Rosalind M Eggo, Nicholas Davies, Mark Jit, et al. "The Effect of Control Strategies to Reduce Social Mixing On Outcomes of the Covid-19 Epidemic in Wuhan, China: A Modelling Study." The Lancet Public Health 5, no. 5 (May 2020): e261-e270.

Qudsia, Miatul. "Maqashid Syariah Sebagai Basis Fiqih Tranformatif Untuk Peningkatan Kualitas Komunitas Petani." Last modified Oktober 2019. Accessed July 15, 2020. https://www.nu.or.id/post/read/112434/maqashid-syariahsebagai-basis-fiqih-tranformatif-untuk-peningkatan-kualitas-komunitas-petani.

Qudsy, Saifuddin Zuhri, and Ahmad Sholahuddin. "Kredibilitas Hadis dalam COVID19: Studi atas Bażl al-Mā'ūn fi Fadhli al-Thāun karya Ibnu Hajar al-Asqalany." AL QUDS : Jurnal Studi Alquran dan Hadis 4, no. 1 (May 11, 2020): 1.

Rahman, Arifur, and Atanu Sarkar. "Risk Factors for Fatal Middle East Respiratory Syndrome Coronavirus Infections in Saudi Arabia: Analysis of the WHO Line List, 2013-2018." American Journal of Public Health 109, no. 9 (July 18, 2019): 12881293.

Raja, AlAnoud TofailAhmed, Aws Alshamsan, and Ahmed Al-jedai. "Current Covid19 Vaccine Candidates: Implications in the Saudi Population." Saudi Pharmaceutical Journal 28, no. 12 (December 1, 2020): 1743-1748.

Rakhman, Alwi Bani. "Teologi Sosial; Keniscayaan Keberagamaan yang Islami Berbasis Kemanusiaan." ESENSIA: Jurnal Ilmu-Ilmu Ushuluddin 14, no. 2 (October 22, 2013): 161.

republika.id. "Thaun Dan Waba Dalam Turos Ulama." Republika.Id. Last modified July 14, 2020. Accessed July 15, 2020. https://republika.id/posts/5760/thaun-danwaba-dalam-turos-ulama.

Reuters. "Chinese Citizens Turn to Virus Tracker Apps to Avoid Infected Neighborhoods." NBC News. Last modified February 4, 2020. Accessed August 15, 2021. https://www.nbcnews.com/tech/social-media/chinese-citizens-turnvirus-tracker-apps-avoid-infected-neighborhoods-n1129111.

Said, Muhammad. "Paradigma Teologi Sosial: Revitalisasi Fungsi Teologi Islam dalam Konteks Multikultural." Jurnal Al-Irfani 3, no. 1 (n.d.): 46.

Sasongko, Agung. "Mengenal Sistem Pengobatan Dalam Islam." Republika.Co.Id. Last modified Oktober 201AD. Accessed August 15, 2021. https://www.republika.co.id/berita/pfyq8h313/mengenal-sistem-pengobatandalam-islam.

Shereen, Muhammad Adnan, Suliman Khan, Abeer Kazmi, Nadia Bashir, and Rabeea Siddique. "Covid-19 Infection: Origin, Transmission, and Characteristics of Human Coronaviruses." Journal of Advanced Research 24 (July 2020): 91-98.

Suyadi, Zalik Nuryana, and Niki Alma Febriana Fauzi. "The Fiqh Of Disaster: The Mitigation of Covid-19 in the Perspective of Islamic Education-Neuroscience." International Journal of Disaster Risk Reduction 51 (December 1, 2020): 101848.

Syarif, Zainuddin, and Abd Hannan. "Fundamentalism and the Challenges of Religious Moderation in the New Normal Era." Madania: Jurnal Kajian Keislaman 25, no. 1 (July https:// ejournal.iainbengkulu.ac.id/index.php/madania/article/view/4260.

Syarif, Zainuddin, and Abd Hannan. "Fundamentalism and the Challenges of Religious Moderation in the New Normal Era." Madania: Jurnal Kajian Keislaman 25, no. 11 (July $1, \quad$ 2021). https:// ejournal.iainbengkulu.ac.id/index.php/madania/article/view/ 4260.

Wamsley, Laurel. "England Has Lifted Most Of Its COVID-19 Restrictions, Even As U.K. Cases Are Up 41\%." NPR, July 19, 2021, sec. The Coronavirus Crisis. 
Accessed August 15, 2021. https://www.npr.org/sections/coronavirus-liveupdates/2021/07/19/1017877573/england-has-lifted-most-of-its-covid-19restrictions.

WHO. "WHO Validates Sinovac Covid-19 Vaccine For Emergency Use and Issues Interim Policy Recommendations." Www.Who.Int. Last modified June 1, 2021. Accessed August 15, 2021. https://www.who.int/news/item/01-06-2021-whovalidates-sinovac-covid-19-vaccine-for-emergency-use-and-issues-interim-policyrecommendations.

Wijaya, Abadi. "Peran Agama Dalam Mengatasi Virus Corona." Www.UinMalang.Ac.Id. Last modified April 20, 2020. Accessed July 4, 2020. https://www.uin-malang.ac.id/blog/post/read/200401/ peran-agama-dalammengatasi-virus-corona.html.

Wong, Martin C.S., Eliza L.Y. Wong, Junjie Huang, Annie W.L. Cheung, Kevin Law, Marc K.C. Chong, Rita W.Y. Ng, et al. "Acceptance of the Covid-19 Vaccine Based on the Health Belief Model: A Population-Based Survey in Hong Kong." Vaccine 39, no. 7 (February 12, 2021): 1148-1156.

$\mathrm{Wu}$, Aiping, Yousong Peng, Baoying Huang, Xiao Ding, Xianyue Wang, Peihua Niu, Jing Meng, et al. "Genome Composition and Divergence of the Novel Coronavirus (2019-NCoV) Originating in China." Cell Host E Microbe 27, no. 3 (March 2020): 325-328.

Wu, Yi-Chi, Ching-Sung Chen, and Yu-Jiun Chan. "The Outbreak of COVID-19: An Overview." Journal of the Chinese Medical Association 83, no. 3 (March 2020): 217220.

“COVID-19: Vaccine Side Effects and Reactions." Ministry of Health NZ. Last modified August 12, 2021. Accessed August 15, 2021. https://www.health.govt.nz/ourwork/diseases-and-conditions/covid-19-novel-coronavirus/covid-19vaccines/covid-19-vaccine-side-effects-and-reactions. 
